Abstracta Iranica Abstracta Iranica

Revue bibliographique pour le domaine irano-aryen

Volume 30 | 2010

Comptes rendus des publications de 2007

\title{
"The untold story of the fight for human rights ». Journal of Democracy, vol. 18, n 4, 2007, pp. 64-79.
}

\section{Anicée Van Engeland}

\section{(2) OpenEdition}

1 Journals

Édition électronique

URL : http://journals.openedition.org/abstractairanica/38062

DOI : 10.4000/abstractairanica.38062

ISSN : 1961-960X

\section{Éditeur :}

CNRS (UMR 7528 Mondes iraniens et indiens), Éditions de l'IFRI

\section{Édition imprimée}

Date de publication : 8 avril 2010

ISSN : 0240-8910

\section{Référence électronique}

Anicée Van Engeland, « «The untold story of the fight for human rights ». Journal of Democracy, vol. 18, n 4, 2007, pp. 64-79. », Abstracta Iranica [En ligne], Volume 30 | 2010, document 287, mis en ligne le 08 avril 2010, consulté le 26 septembre 2020. URL : http://journals.openedition.org/abstractairanica/ 38062 ; DOI : https://doi.org/10.4000/abstractairanica.38062

Ce document a été généré automatiquement le 26 septembre 2020.

Tous droits réservés 


\section{" The untold story of the fight for human rights ». Journal of Democracy, vol. 18, n 4, 2007, pp. 64-79.}

\section{Anicée Van Engeland}

L'A. s'intéresse aux actions menées par la société civile dans le cadre d'un gouvernement traditionaliste. Elle explique pourquoi la société civile iranienne est un symbole plein d'espoir dans une région où les droits de l'homme peinent à s'établir. L'article conclut sur la nécessité pour les pouvoirs occidentaux de soutenir les efforts de la société civile.

INDEX

Thèmes : 12.1. Iran

\section{AUTEURS}

\section{ANICÉE VAN ENGELAND}

European University Institute - Florence 